Avery, MacLeod, McCarty discovery, it is no longer possible to maintain that their paper was either ignored or unknown. When we see how little was known about genetic processes in bacteria and the chemistry of DNA in 1944 compared with 1950, Avery's caution can be seen as justified. As for the geneticists, it is clear that what caught their imagination was not the identity of the transforming principlewhether it was nucleic acid or nucleoprotein did not mean a great deal to them-but the possibility, at last, to bring about a given hereditary change by a specific treatment. Hence the reason for the widespread habit of referring to bacterial transformation as "directed mutation".

H. J. Muller was exceptional among geneticists in being concerned about the chemical identity of Avery's transforming principle, but was impressed by Mirsky's opinion. To Darlington he wrote: ". . Mirsky gave reasons for believing that Avery's so-called nucleic acid is probably nucleoprotein after all ...."18. Yet again, what attracted Muller was the possibility of fitting transformation into the grand scheme of cytogenetics. In the transforming substance, he suggested, there were chromosomal fragments consisting of nucleoprotein, which were incorporated into the genetic apparatus of the recipient bacterium in transformation.

As in the case of Mendel's paper, the scientists of a given period found in Avery's paper what they were looking for, but unlike that earlier case, the 1944 paper was not ignored or unknown. It posed questions about DNA which by 1950 could be answered. What Avery failed to say, Boivin said, but his brave words did not profoundly alter the climate of opinion until the Boivin Vendrely Rule was established ${ }^{19}$. Only with the advantage of hindsight can we see the significance of the 1944 paper as obvious. Only by confining our attention to the published record and the citation statistics on Avery's paper can we arrive at the view that it was little known or undervalued.

Yours faithfully,

R. OlbY

Department of Philosophy,

University of Leeds,

Leeds $L S 29 \mathrm{JT}$

1 Wyatt, H. V., Nature, 235, 86 (1972)

2 Hotchkiss, R. D., in Phage and the Origins of Molecular Biology (edit. by Cairns, J. Stent, G. S., and Watson, J. D.) (Cold Spring Harbor Laboratory, 1966).

${ }^{3}$ Robinow, C. F., Proc. Roy. Soc., B, 130, 299 (1942)

${ }^{4}$ Lederberg, J., and Tatum, E. L., Nature, 158, 558 (1946).

${ }^{5}$ Neufeld, F., and Levinthal, W., $Z$. Immunitatsforsch. Exp. Ther., 55, 324 (1928).

${ }^{6}$ Dawson, M. H., J. Exp. Med., 51, 143 (1930).

7 Alloway, J. L., J. Exp. Med., 57, 265 (1933).

8 McCarty, M., and Avery, O. T., J. Exp. Med., 83, 89 (1946).

9 Avery, O. T., MacLeod, C., and McCarty, M., J. Exp. Med., 79, 137 (1944).

10 Mirsky, A. E., Cold Spring Harbor Symp. Quant. Biol., 12, 16 (1947).

${ }^{11}$ Boivin, A., Vendrely, R., and Lehoult, Y., C.R. Acad. Sci., Paris, 221, 646 (1945)

12 Avadhani, N.-G., Mehta, B. M., and Rege, D. V., J. Mol. Biol., 42, 413 (1969).

13 Boivin, A., Delaunay, A., Vendrely, R. and Lehoult, Y., Experientia, 1, 334 (1945).

14 Boivin, A., Cold Spring Harbor Symp. Ouant. Biol., 12, 7 (1947).

15 Tulasne, R., CR Seanc. Soc. Biol., 141, 411 (1947).

16 Vendrely, R., and Lipardy, J., C.R. Acad. Sci., Paris, 223, 342 (1946).

17 Tulasne, R., and Vendrely, R., C.R Seanc. Soc. Biol., 141, 674 (1947).

18 Letter from H. J. Muller to C. D. Darling ton dated March 2, 1946.

19 Boivin, A., Vendrely, R., and Vendrely, C., C.R. Acad. Sci., 226, 1061 (1948).

\section{Peregrines and Propaganda}

SIR,-Dr Cramp writes that "there is more than propaganda to justify the belief that the persistent pesticides led to striking declines in peregrines" (Nature, 238, 475; 1972). He then refers to evidence, as if the existence of evidence sufficed to make the case, irrespective of contrary evidence or unsoundness. But rarely is there absolutely no evidence behind propaganda. In this case, the evidence was examined by the Wilson Committee ${ }^{1}$ and the Mrak Commission ${ }^{2}$ and found to be inadequate.

Dr Cramps chides me for not quoting the Wilson Report for the suggestion that dieldrin was responsible; but that was just a suggestion and not altogether convincing. In this country, for most purposes the small tonnages of dieldrin and DDT used could be replaced by other insecticides, as recommended by the Wilson Committee, because there were few disadvantages in doing so. But the balance of advantage would be quite different in some countries, where the lives and happiness of many millions of human beings would be put at risk by abandoning DDT and dieldrin. In those countries, much more rigorous examination of and search for evidence would be essential and mere suggestions ought not to be lightly accepted. In particular, in this country and in North America, suggestions and insufficient evidence are converted by propaganda into beliefs ${ }^{3}$; such beliefs will be accepted by malarious countries at their peril.

Yours faithfully,

\section{L. GunN}

\section{Chilham,}

Kent

${ }^{1}$ Advisory Committee on Pesticides and other Toxic Chemicals, 148 (HMSO, 1969).

2Report of the Secretary's Commission on Pesticides and their Relationship to Environmental Health, 677 (US Department of Health, Education and Welfare, 1969).

${ }^{3}$ Gunn, D. L., Ann. Appl. Biol., 72 (in the press).

\section{HOW TO BUY NATURE}

Volumes start in January, March, May, July, September and November, but subscriptions may begin at any time. The direct postal price per subscription is: 12 MONTHS * (52 issues per title)

$\begin{array}{lcc} & \begin{array}{c}\text { Surface mail } \\ \text { UK and } \\ \text { worldwide } \\ \text { Nature (Friday) }\end{array} & \begin{array}{c}\text { U.S.A. and } \\ \text { Canada }\end{array} \\ \begin{array}{l}\text { Nature + } \\ \text { Nature Physical Science }\end{array} & £ 24 & \$ 48 \\ \begin{array}{l}\text { Nature + } \\ \text { Nature New Biology }\end{array} & £ 24 & \$ 83 \\ \text { All three editions } & £ 29.50 & \$ 108 \\ \text { Annual Index } & £ 1 & \$ 3\end{array}$

* Rates for shorter periods pro rata (minimum three months) (Charge for delivery by air mail on application)
Editorial and Publishing Offices of NATURE

MACMILLAN JOURNALS LIMITED

4 LITTLE ESSEX STREET, LONDON WC2R 3LF Telephone Number: $01-836$ 6633. Telegrams : Phusis London WC2R 3LF Telex 262024

711 NATIONAL PRESS BUILDING WASHINGTON DC 20004

Telephone Number : 202-737 2355. Telex 64280 Subscription Department

MACMILLAN JOURNALS LIMITED

BRUNEL ROAD, BASINGSTOKE, HANTS

Telephone Number : Basingstoke 29242

American display advertisements

NATURE SCIENTIFIC PUBLICATIONS INC

711 NATIONAL PRESS BUILDING WASHINGTON DC 20004

All other advertisements

T. G. SCOTT \& SON, LIMITED

1 CLEMENT'S INN, LONDON WC2A 2ED

Telephone : 01-242 6264/01-405 4743

Telegrams: Textualist London WC2A 2ED

Registered as a newspaper at the Post Office

Copyright (C) Macmillan Journals Limited. September 291972 